\title{
Challenges of Implementing Service-Learning Pedagogy In Nigeria Public Universities
}

\author{
Lillian I.Olagoke-Oladokun ${ }^{\mathrm{a}}$,*, Mahani Mokhtar ${ }^{\mathrm{b}}$, Zainudin Hassan ${ }^{\mathrm{c}}$, Sanitah Yusof ${ }^{\mathrm{d}}$, Marlina Ali ${ }^{\mathrm{e}}$, Shahrin \\ Hashim ${ }^{\mathrm{f}}$
}

a,b,c,d,e,f School of Education and Humanities, Universiti Teknologi Malaysia, Malaysia;

alilliangoke@gmail.com, ${ }^{\mathrm{b}}$ - -mahani@utm.myb,p-zainudin@utm.my ${ }^{\mathrm{c}}$, p-sanitah@utm.my ${ }^{\mathrm{d},}$ p-marlina@utm.my ${ }^{\mathrm{e}}$.P sharin@utm.my ${ }^{\mathrm{f}}$

*Corresponding Author: lilliangoke@gmail.com

Article History: Received: 10 November 2020; Revised 12 January 2021 Accepted: 27 January 2021; Published online: 5 April 2021

\begin{abstract}
Service-learning is a form of experiential learning that enables students to apply the knowledge acquired in the classroom towards the development of their immediate environment. Service-learning as experiential learning advocates active learning contrary to the passive form of learning associated with the traditional method of teaching and learning in most Nigerian public universities. This study explores the challenges encountered by students in Nigeria public universities during service-learning implementation. Participants: Students and faculty members were interviewed to generate information from their life experiences of service-learning implementation. The data gathered using semi-structured interview questions were transcribed and coded using the NVIVO software to generate themes. Findings showed inadequate time, inadequate knowledge of implementation, lack of funds, lack of co-operation among students during the implementation, inadequate supervision, and a structured guideline for service-learning implementation and logistics as the major challenges associated with adopting service-learning as a form of learning in Nigeria public universities
\end{abstract}

Keywords: Nigeria universities, Service-learning, challenges, Active learning, Experiential learning

\section{Introduction}

Recent studies showed public universities in Nigeria like their counterparts in other parts of the world have adopted the use of experiential learning methods in replacement of the traditional method of teaching and learning often referred to as the storytelling methods (Gbadamosi, 2018). Experiential form of learning involves students actively participating in the learning process, it entails the immediate hands-on experience of what is being taught in the classroom for learning. The experiential method of learning is preferred because it enables the learners to create knowledge through the transformation of their gained experiences (A. Y. K. D. A. Kolb, 2017; D. A. Kolb, 2014). Studies showed different types of experiential learning methods often adopted by higher universities as institutions such as community service, field trip, volunteerism, service-learning, internship (Fenton \& Gallant, 2016; Miettinen, 2000)

Most higher institutions of learning advocated the use of experiential learning and service-learning is often the most ubiquitously adopted due to the numerous observable benefits on the participants (Maakrun, 2016; Schoenherr, 2015). According to Dewey (2004) and Burth (2016), service-learning is regarded as a philosophy as well as an instructional method. The philosophical point of service-learning believes every form of education should enhance individual development by encouraging students' social responsibility through active citizenship in society. While Service-learning as an instructional medium involves integrating service activities into the academic curriculum to solve real community needs while students learn through active engagement and reflection(Burth, 2016; Tyran, 2017). Recorded impact of service-learning cuts across both the giver and the recipient an important attribute that differentiates service-learning from other forms of experiential learning(Knapp, Fisher, \& Levesque-Bristol, 2010). Studies proved service-learning as a form of pedagogy improves students' academic performance as students construct new knowledge from their experiences and ability to relate their experience with the theoretical knowledge obtained in the classroom through reflection(Brondani, 2012). The service-learning pedagogy is only been recently adopted in the Nigeria education settings and few studies have proven how beneficial the service-learning pedagogy is among participants especially the students in Nigeria public universities(Deba, Jabor, Buntat, \& Musta'mal, 2014; Olagoke-Oladokun, Mokhtar, Gbadamosi, \& Dugguh, 2020).

However, being a new pedagogy, what are the challenges experienced by the participants during the implementation process in the context of the Nigeria higher education system. However, little, or no documented evidence has surfaced to the effect in relation to service-learning pedagogy in the context of Nigeria's education 
system unlike as found in the literatures on implemented service-learning activities in the other part of the world. Therefore the objective of this study is to investigate the challenges experienced by students, institutions, and communities during the implementation of Service-learning project.

\section{Literature Review}

A quantitative study conducted by Abes, Jackson, and Jones (2002) identified possible factors that hinder and strains the implementation of service-learning as a form of pedagogy is its lack of recognition in the faculty as a form of academic activity and justifies such with lack of time to learn how to use service-learning as a form of teaching and learning because of its possible effect on their productivity to prior assigned professional responsibilities.

Bringle, Clayton, and Price (2012) identified service-learning as a program that requires adequate time for effective planning and the execution process regrettably, inadequate time for the process was identified as another major constraint in service-learning implementation. The time factor is an important consideration in servicelearning pedagogy as service-learning can be considered as standard if it lasts for a considerable duration with intensity (Corporation., 2009). However, the time factor has been considered as the most prevalent difficulty as there is usually a collision of planned activities in service-learning projects with other responsibilities in the school among participants. Insufficient time for the preliminary stages of service-learning such as planning, investigation, and implementation is usually a condition recorded among service-learning participants. Often students recorded insufficient time to accomplish most of the outlined activities during the implementation process. This has often been recorded to impede the (C.B. Kaye, 2010; Cathryn Berger Kaye, 2013). Evidence showed students complained of inadequate time to accomplish designated roles due to other academic responsibilities. Having identified time as a critical determinant in the outcome of service-learning implementation, time-related when not properly managed may affect the learning outcome and meeting the needs of the community(Abes et al., 2002; Spring, Grimm Jr, \& Dietz, 2008). Another study identified lack of time as the main factor for refusal to adopt service-learning by faculty members this many faculty members attributed to as additional workload(Palmer \& Savoie, 2002)

Darby and Newman (2014) in a qualitative study on what motivates students and challenges for servicelearning found transportation and time as major sets backs in service-learning pedagogy. This correlates with findings from Abes et al. (2002) who identified inadequate time for planning and implementation as a major challenge in the service-learning pedagogy. In separate studies, lack of funds was found to be another major challenge in adopting and implementing service-learning as a form of pedagogy. This challenge was usually encountered by most institutions with no intention to adopt service-learning as a form of pedagogy thereby leaving the faculty members with no choice but to look for an external source for funds(Al Barwani, Al-Mekhlafi, \& Nagaratnam, 2013; Fiske, 2002). Aside from the issues of time raised in his studies, Mileusnić (2020) identified the logistical challenges, the interpersonal relationship among team members and the organizations as well as unusual participation of all team members during the project implementation process and in other roles delegated to them. The study also identified, difficulty in controlling what students can learn during this period. This can possibly be due to the constructivism nature of service-learning where individual student construct their knowledge from their experiences in the field(Mayer, 2009; Young et al., 2015). Student supervision and assessment of all projects by faculty members were identified as another challenging case in service-learning implementation especially that which involves. This becomes more challenging in cases where there is a big disparity ratio between faculty staff and the students(Tryon et al., 2008). In a study conducted by Schelbe, Petracchi, and Weaver (2014), students identified the time for service-learning to be overwhelming the time and those who are part-time workers find it difficult to balance between working and being a student. This was shown to affect productivity at work and learning outcomes in school.

Issue related to logistics or transportation was identified as one of the challenges identified with the implementation of service-learning. Studies showed the movement of participants especially the students from campus to the location where projects would be implemented is significant to the success of the program. Availability of adequate and reliable means of transportation will not only aid the fast and easy movement of the participants to location but guarantees safety for participants especially the students(Wade, 1997). Problems related to transportation usually occur when there is delay and poor arrangement of how to convey students to site where service-learning will be conducted especially among students. Logistics also related to the coordination of participants at the service-learning site. Lack of control of students at the site of service-learning leads to a disruption in the service-learning implementation which can have an effect on the learning outcome and in meeting the needs of the community involved(Schelbe et al., 2014).

The identified document literature is proof that there are challenges associated with service-learning implementation. However, many of these factors were passively identified alongside studies related to servicelearning implementation (Morton, 1995; Schelbe et al., 2014; Wade, 1997). Although possible challenges were 
identified, there was no recorded proof on how and what solution can be proffered to the identified challenges by the students and faculty members. Although major activities in service-learning implementation activities are relegated to students because the major aim of service-learning is towards their holistic development hence, most studies related to benefits and challenges are focused on students' experiences, and not all involved participants.(Rusu, Copaci, \& Soos, 2015; Stewart \& Wubbena, 2014). Similarly, challenges identified in servicelearning activities are usually students related. Hence this study is motivated to explore and identify challenges related to service-learning implementation in Nigerian Public universities.

\section{Methodology}

This study employed a qualitative research approach and interpretivism paradigm to generate data for the study while the respondents were sampled through purposeful sampling methods. By interpretivism process, the research problem is being studied in its natural setting rather than in a laboratory because the researcher believes the participants had a first-hand experience of the phenomenon which is been studied and the meanings or conclusions of this study can only emerge towards the end of the research process from the interview data (Brown, 2006; J. W Creswell, 2007). This allows for information to be gathered from multiple sources to understand the phenomenon through the participants. The data gives in-depth information and a deeper understanding of the phenomenon (Miles \& Huberman, 1994). Open-ended questions were prepared to gather information and this allowed the participants to provide information without restriction (J. W Creswell \& Clark, 2011). The purposive sampling technique involves the selection of a group of undergraduate students from Nigerian public universities who have actively participated in service-learning implementation. A detailed semi-structured interview was conducted among 25 participants made up of 22 students and 3 academic staff.

The main questions of focus were based on the main objective of the study which is to identify the challenges involved in the implementation of service-learning and the possible proffered solutions to the identified challenges. The interview questions are the followings:

1. Students

- What are the challenges experienced in the SL project implementation?

- How did you address those challenges of SL project implementation?

- How did the challenges of SL project implementation affect your learning outcome?

- What difficulties did you experience in organizing all participants in the SL project implementation?

2. Lecturers

- What are the challenges encountered using SL project implementation?

- How did you address those challenges of SL project implementation?

- How did challenges of SL project implementation affect students' learning outcomes?

Of the 25 selected participants in this study, the interview ended when the data collected had reached the saturation point on the 19th participant; a point at which there was no more new information supplied by the participants during the interview. To validate collected data, the member checking method was adopted due to the nature of the study to achieve the objectives of the study as supported by John W Creswell (2012). The member checking technique involved the researchers asking the participants after being interviewed to go through what they said to confirm if their ideas have been represented correctly in the transcript. This was to obtain holistically 'valid' results (Cho \& Trent, 2006; Malterud, 2001). The analysis followed the process of Interpretative Phenomenological Analysis (IPA) as described by Ojala (2008) and Smith and Osborn (2003) through which the transcribed interview data were read and reread to examine and code ideas Using the NIVO software, codes were generated, and themes were formed. The generated codes were collated, and fitting excerpts were matched. Codes were grouped to form themes after which similar themes were merged. The generated themes are brought together from the narrative which is the logical interpretative analysis of the data by the researcher.

Table 1. Categories and fragments used in the content analysis of the interviews.

\begin{tabular}{|c|c|}
\hline Categories & Fragments \\
\hline Financial Challenges & $\begin{array}{ll} & \text { Lack of partnership } \\
- & \text { Lack of financial support from the institution }\end{array}$ \\
\hline Socially Induced Challenges & $\begin{array}{ll}- & \text { Language barrier } \\
\text { - } & \text { Social resentment }\end{array}$ \\
\hline Poor Knowledge of Implementation & $\begin{array}{ll}\text { - } & \text { Difficulty in evaluating. } \\
\text { - } & \text { Lack of knowledge of assessment } \\
\text { - } & \text { Difficulty to link relevant curriculum }\end{array}$ \\
\hline
\end{tabular}




\begin{tabular}{|c|c|}
\hline Time Constraints & $\begin{array}{ll}- & \text { Insufficient time } \\
\text { - } & \text { No designated time }\end{array}$ \\
\hline $\begin{array}{l}\text { Students Negative } \\
\text { Induced Challenges }\end{array}$ & $\begin{array}{ll}- & \text { Lack of interest } \\
\text { - } & \text { Lack of cooperation }\end{array}$ \\
\hline Institutional Deficiencies & $\begin{array}{ll}\text { - } & \text { Undocumented past SL } \\
\text { - } & \text { Lack of indigenous SL manual } \\
\text { - } & \text { Insufficient facilitators } \\
\text { - } & \text { Untrained facilitators } \\
\text { - } & \text { Lack of SL integration }\end{array}$ \\
\hline
\end{tabular}

\section{Results and Discussion}

The discussion of the results and findings of this study revolves majorly around the main objectives of this study as earlier mentioned which is to explore the challenges related to service-learning implementation and the possible solutions proffered. The model of the theme and subtheme is displayed in Figure 1. The challenges identified by Nigerian students during service-learning were identified as financial challenges, socially induced challenges, poor knowledge of implementation, time constraints, students' negative attitudinally induced challenges, and institutional deficiencies.

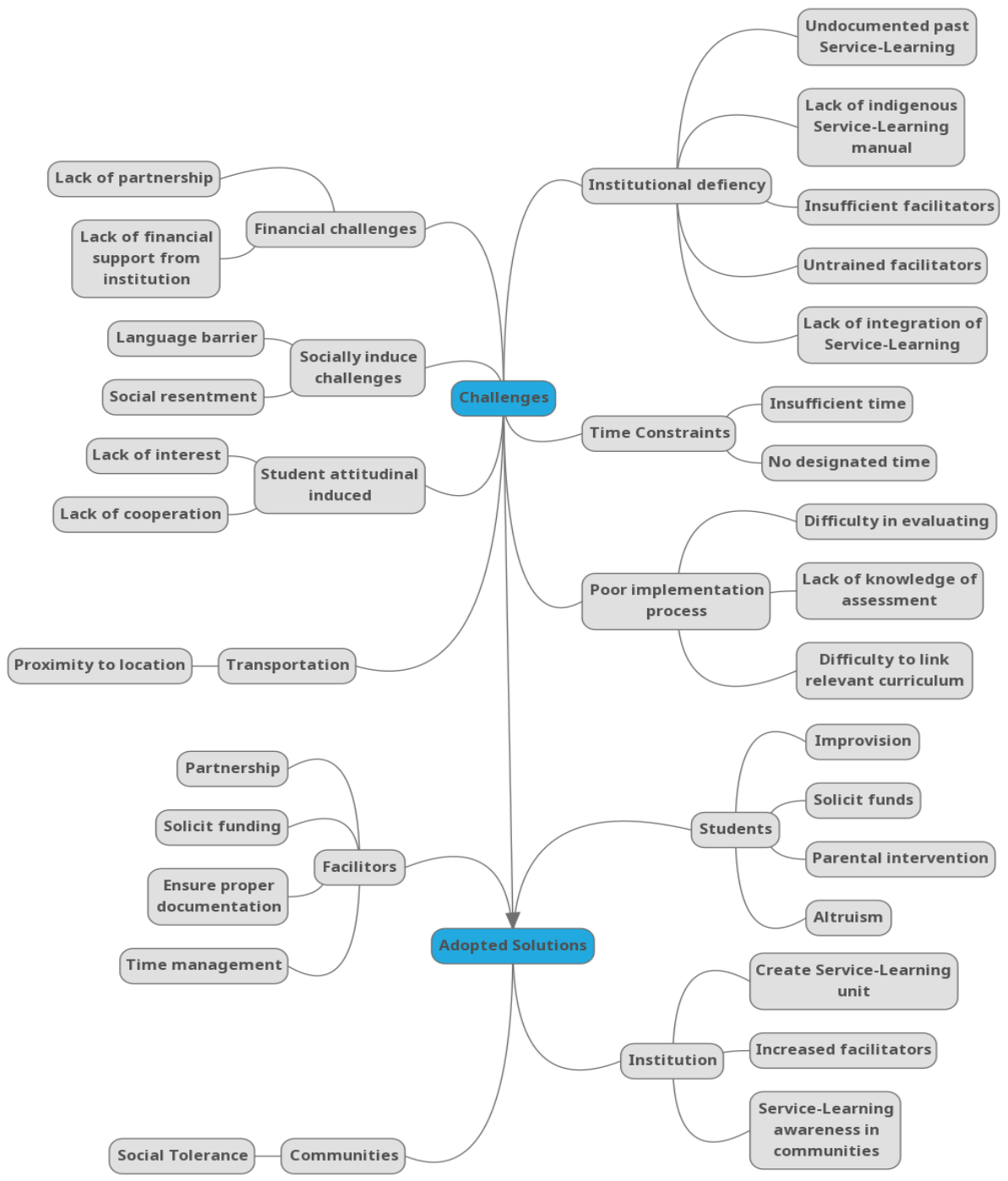

Figure 1Challenges of service-learning themes and subtheme Map 
The challenges investigated and explored and the finding deduced from the qualitative analysis are discussed in sections 4.1.1 to 4.1.7 below. These difficulties encountered in Service-Learning implementation by the Students, Institutions (University), Faculties, Communities include Financial challenges, Socially induced challenges, Poor knowledge of implementation, Time constraints, Students' negative attitudinally induced challenges, and Institutional deficiencies.

\subsubsection{Financial Challenges}

This study showed students experienced financial difficulties in service-learning activities due to a lack of financial support from the institution see excerpts in Table 2. Findings showed students resulted in solving financial challenges through personal savings through parental interventions, supports from friends, and other organizations. The facilitators also attested to the difficult financial challenges students go through to implement service-learning projects. Lack of finances is due to the lack of insufficient funds for service-learning implementation, students, therefore, take projects which demand fewer funds that they can conveniently sponsor.

Table 2. Category and excerpts extracted from the interviews for Financial Challenges.

\begin{tabular}{|c|c|}
\hline Category & Excerpts \\
\hline \multirow{5}{*}{$\begin{array}{l}\text { Financial } \\
\text { Challenges }\end{array}$} & $\begin{array}{l}\text { "I was able to raise some funds before I started the SL the first challenge I } \\
\text { discovered then was the financial aspect." - Abdul }\end{array}$ \\
\hline & $\begin{array}{l}\text { "The first challenge we came across as students was financing as in how to } \\
\text { raise money" - Dan }\end{array}$ \\
\hline & $\begin{array}{l}\text { "they are the ones that sponsor the project .. they sponsor themselves they } \\
\text { finance it that is why when I asked them to do it for their final year project } \\
\text { they were like ah!!! Mummy how are we going to finance it, "-Giada }\end{array}$ \\
\hline & $\begin{array}{l}\text { "you contribute together to get it done so sometimes students can decide to } \\
\text { pick a problem that will not cause them much, do you get me now because no } \\
\text { lecturer will use their money to finance them"-Oye }\end{array}$ \\
\hline & $\begin{array}{l}\text { "Yes they do, the financial problem can affect because while cutting cost, } \\
\text { there are some benefits that the students would have gotten that I would have } \\
\text { removed"-Vicks. }\end{array}$ \\
\hline
\end{tabular}

Besides implementing projects that involved fewer funds, students improvised during this process especially in producing needed items at reduced costs. Although they could be seen as being creative, students attested its negative effect as time-consuming and the learning outcome could also be affected.

\subsubsection{Socially Induced Challenges}

Table 3 shows the excerpts from the interviews for another kind of challenges experienced which was categorized as socially induced during the service-learning implementation are communication barrier, religion and cultural background of the natives, and perceived social resentment. Students from the Northern university identified that the cultural background of the community where they implemented service-learning affected the implementation process particularly at the stage of the investigation process. This is because culturally, the Northern women are secluded from the opposite gender in public and cannot be engaged in discussion without the permission or the presence of their spouse. This was observed to have affected investigating the needs of the community from the female gender as it was necessary to seek the consent of all community members before the implementation began.

Table 3. Category and excerpts extracted from the interviews for Socially Induced Challenges. 


\begin{tabular}{|c|c|}
\hline Category & Excerpts \\
\hline \multirow{5}{*}{$\begin{array}{l}\text { Socially } \\
\text { Induced } \\
\text { Challenges }\end{array}$} & $\begin{array}{l}\text { "people like the Fulanis, they are really really hard to talk to and you } \\
\text { know a guy cannot enter into their house and ask their wives if the if the } \\
\text { husband is not there" Muris }\end{array}$ \\
\hline & $\begin{array}{l}\text { "If you don't really have the idea probably of their culture, their belief } \\
\text { system might actually limit somethings, you might have difficulty in carrying } \\
\text { out the SL" Arin }\end{array}$ \\
\hline & $\begin{array}{l}\text { "And another challenges encountered was communication... } \\
\text { communication with the community because it is the very local community } \\
\text { who cannot really speak Hausa"-Jay }\end{array}$ \\
\hline & $\begin{array}{l}\text { "the challenges I experienced .. some people if you go to them.. ask them } \\
\text { they will even send you away, they are not even willing to answer you at all } \\
. "-\text { Muris }\end{array}$ \\
\hline & $\begin{array}{l}\text { "Our fear was our children will be polluted with a bad character } \\
\text { because it is the belief in the community that university students have a bad } \\
\text { character that is the notion in the village" - Kefs }\end{array}$ \\
\hline
\end{tabular}

Similarly, another student, attested that cultural differences between the participants and the host community affected the implementation of service-learning. Findings showed communication barriers as a major challenge between the students and the community members. This is because Nigeria is a multi-ethnic society with different languages. Communication barriers existed because most students in Northern Nigeria are not indigenes of that locality and do not understand the dialect of the locals see Table 3.

Students perceived social resentment from the community members due to the observed community's lack of support This was further confirmed by the members who disclosed fear of having the children's moral standard compromised within the community. The reaction from a member of the community was a typical display of the belief an average Nigerians have of the university students and the assumption that university students are associated with promiscuity and being perverted see excerpt statements in Table 3

\subsubsection{Time Constraint Challenges}

Time constraints were a major factor identified to have impeded the implementation of service-learning amongst these participants. The study showed a lack of designated time for the implementation and insufficient time for the execution of the planned activities were the major concern regarding time challenges during servicelearning implementation see Table 4 for the excerpts.

Lack of designated time for the implementation of service-learning was a major factor where the servicelearning timetable had not been inculcated into the official university timetable. It can therefore be inferred as the reason for the students' commitment towards the planning of service-learning.

Table 4. Category and excerpts extracted from the interviews for. Time Constraint Challenges. 


\begin{tabular}{|l|l|}
\hline Category & Excerpts \\
\hline \multirow{5}{*}{$\begin{array}{l}\text { Time } \\
\text { Constraint } \\
\text { Challenges }\end{array}$} & $\begin{array}{l}\text { "the first thing is that the kind of the time table, the university timetable and } \\
\text { the calendar does not give room for students to render to do somethings as a } \\
\text { result of the volume of the work"-Gbada }\end{array}$ \\
\cline { 2 - 2 } & $\begin{array}{l}\text { "So going back to time now we are students, also have things to do at the } \\
\text { faculty attend classes, we have a test to write an assignment to read for being } \\
\text { a student some of my team members some of them are aged people some of } \\
\text { coming to school the time between shuffling academics your home issues and } \\
\text { then having to create time for SL, it is time-consuming"-Toyin }\end{array}$ \\
\cline { 2 - 2 } & $\begin{array}{l}\text { "during the implementation.. different people and different time schedules. } \\
\text { some people had work even after school, some they... I think it was courses } \\
\text { they were not really from the same teaching course. some were from } \\
\text { geography and they had different timetables. so having to see when they are } \\
\text { free and when we are free. so we can all meet" - Cy }\end{array}$ \\
\hline
\end{tabular}

\subsubsection{Poor Knowledge of Implementation}

On poor knowledge of implementation, difficulties in choosing to meet needs and relevant curriculum, difficulties in the assessment of projects, difficulties in evaluating projects, lack of knowledge of assessment were sub-themes discovered.

Participants especially the students encountered difficulties in making decisions to meet the needs relevant to the curriculum and to fit into the financial capacity of the group. It can therefore be said that financial capacity and knowledge of the relevant project to fit into the curriculum determined the type of project to be implemented see Table 5. Findings showed difficulties in evaluating and assessing projects implemented. This was due to the lack of knowledge on how to implement and what to be evaluated by the participants of service-learning.

Table 5. Category and excerpts extracted from the interviews for Poor Knowledge of Implementation Challenges.

\begin{tabular}{|c|c|}
\hline Category & Excerpts \\
\hline \multirow{4}{*}{$\begin{array}{l}\text { Poor Knowledge of } \\
\text { Implementation }\end{array}$} & $\begin{array}{l}\text { "okay fine we also had the same issue while we were identifying problems to submit } \\
\text { to our lecturer for verification and approval you know some of us wanted to go into } \\
\text { the market community.. some of us wanted to go into the residential community in } \\
\text { Nigeria, there will always be so many problems for one to talk about; academically } \\
\text { socially, politically"-Toyin }\end{array}$ \\
\hline & $\begin{array}{l}\text { "so we are still looking for a way to evaluate either on a sectional basis like for this } \\
\text { particular session of the students' affairs, their cognitive or their affective or their } \\
\text { psychomotor domains. maybe that is what we will come up with now we are still } \\
\text { having issues with what our evaluation sheet is gonna look like and how the } \\
\text { evaluation should be done" Toyin }\end{array}$ \\
\hline & $\begin{array}{l}\text { "Difficult to determine in the sense that if you want to measure how beneficial it is to } \\
\text { the community, it will depend on certain factors..okay...... . Training in skills, skills } \\
\text { acquisition .... It is difficult to measure because if you want to measure okay.. - Udy }\end{array}$ \\
\hline & $\begin{array}{l}\text { "Nobody assessed it because we .. write project we recorded it as a video so we now } \\
\text { submit it to her but the first one I was telling you about we did not invite them so we } \\
\text { can not say we did it because they did not come and assess us. She told us to record it } \\
\text { and then told us to send a video to her. That was how it was assessed" - Doris }\end{array}$ \\
\hline
\end{tabular}

From the excerpts in Table 5 assessment of implemented service-learning was another challenging experience recorded by the students and facilitators during the implementation process. Students identified that projects were virtually assessed without the physical presence of the facilitators. Hence, a form of disappointment was perceived 
by the students during the interview session. The perceived form of disappointment could lead to a displayed unconcerned attitude towards service-learning implementation.

\subsubsection{Students' Negative Attitudinally Induced challenges}

Students' negative attitudinally induced challenges were linked with the attitudes displayed during the planning and the implementation of service-learning. Findings showed students displayed a lack of interest in service-learning implementation which thereafter led to a lack of cooperation amongst the participants. These attitudes were reported to have caused a delay in the implementation process excerpts in Table 6.

Table 6. Category and excerpts extracted from the interviews for Students' Negative Attitudinally Induced Challenges.

\begin{tabular}{|c|c|c|}
\hline Category & & Excerpts \\
\hline \multirow{3}{*}{$\begin{array}{l}\quad \text { Students' } \\
\text { Attitudinally } \\
\text { challenges }\end{array}$} & \multirow{3}{*}{$\begin{array}{l}\text { Negative } \\
\text { Induced }\end{array}$} & $\begin{array}{l}\text { "And secondly is the areas of the students themselves. the students } \\
\text { are not willing to learn they believe all these activities are very obvious } \\
\text { why will they need to go through all these long processes so"-Abdul }\end{array}$ \\
\hline & & $\begin{array}{l}\text { "The lack of interest displayed by students made them } \\
\text { uncontrollable and unresponsive towards duties or roles assigned to } \\
\text { them leading to a delay in the planned activities" - Arin }\end{array}$ \\
\hline & & "They were not cooperating and the awareness was low" - Aves. \\
\hline
\end{tabular}

Although students displayed a lack of interest in the service-learning, the report showed it was short-lived after they gave the program a try. The initial display of lack of interest was attributed to the lack of awareness of the benefit of service-learning as a method of learning as seen in the excerpt. From the excerpt above in Table 6, students and the community members need a sensitization process to educate them on the benefits and the significance of service-learning. This will motivate and make them enthusiastic about the process.

\subsubsection{Institutional Deficiency}

The study showed part of the challenges experienced during the implementation of service-learning were due to the inadequacies on the part of institutions concerned. Findings showed a lack of indigenous service-learning manual, undocumented past service-learning experience, service-learning not adopted by university curriculum, untrained facilitators, insufficient facilitators.

Service-learning is an educational practice that is found to be a novel educational practice in Nigeria public universities, hence the need for a detailed documented guideline for a successful implementation. However, this was shown to be deficient in Nigerian universities. According to one of the facilitators, the lack of structured guidelines for service-learning was one of the difficulties experienced by the students as students had no prior knowledge of service-learning see excerpts in Table 7. Besides recording the absence of a structured detailed service-learning guideline, it was also discovered there were no documented details of past service-learning for students for participants leaving no history of past experiences and leaving participants uninformed.

Table 7. Category and excerpts extracted from the interviews for Institutional Deficiency Challenge.

\begin{tabular}{|l|l|}
\hline Category & Excerpts \\
\hline \multirow{3}{*}{$\begin{array}{l}\text { Institutional } \\
\text { Deficiency } \\
\text { Challenges }\end{array}$} & $\begin{array}{l}\text { "Then another thing is there should be structure some things that should be } \\
\text { put in place something that will serve as a guideline it is not available yes } \\
\text { there is no official guideline except the one we can have online" - Gbada. }\end{array}$ \\
\cline { 2 - 2 } & $\begin{array}{l}\text { "If only we too can have a unit whereby they will be able to document the } \\
\text { activities of the students, we document the needs of the community and we } \\
\text { also document the sponsor that can sponsor some of the project that can } \\
\text { make it to be easier" - Gbada }\end{array}$ \\
\hline
\end{tabular}




\begin{abstract}
"but just a few of them that comply because as a result of their attitude because they complain they are the only one doing it in the whole of the faculty provision because it has not become .. it is not part of the university program. It has not been incorporated into the system" Gbada
\end{abstract}

"Yes definitely like if it has not been incorporated into the university calendar, students do not have time to carry out their services" - Gbada

"Ermm during my time, it was only one lecturer and our numbers were.. you know we are taking it like GST .. General study Course .our number is very high so when he comes him alone for him to be able to communicate to the class at large it will be very difficult" Dan .

“..then the course lecturer inefficiency to supervise the students” Ave

Findings showed an insufficient number of facilitators compared to the number of students and locations where service-learning was implemented. This challenge was deduced to have resulted in poor supervision of the project executed and unsatisfactory support complained by the students as stated in the excerpts in Table 7 .

Due to the insufficient number of facilitators, it can be assumed as the cause for poor implementation process observed in the process of service-learning as students could have been poorly supervised due to the ratio of the number of students to the facilitators. Similarly, students' lack of interest in service-learning can be related to the fact that many institutions have not adopted the use of service-learning as an educational practice in most Nigerian higher institutions. Hence students perceived it as irrelevant and stressor on their academic pursuits as observed in students from Western University see Table 7. Also, it was deduced that lack of designated time for servicelearning implementation was associated with the fact that it was not an officially established educational practice by the institution. This led to a clash of time which made participants not give it a preference.

\title{
4.2. Adopted solutions to service-learning challenges.
}

Financial challenges showed to be the most prevalent among the service-learning participants in Nigeria public universities. Findings showed adequate solutions could not be proffered by the institutions therefore students resulted to seeking financial aid from external sources, improvisation, personal donations an act which possibly led to altruism while the faculty resolved to solicit finances from public organizations, however, some suggested partnerships with industries to build a relationship between the university and the industries for long-term use.

"Ahh.. that is always really tough but then ermmm from experience finances has been handle through. personal savings you could get donations, and most important is ehh.. ability to be resourceful. Our resourcefulness that is always one central saviour when it comes to finances" Udy.

Facilitators identified a lack of designated time for service-learning implementation and therefore resulted in alternating the service-learning pedagogy with the specified time. The time choosing will not infringe on the general timetable however, due to the nature of service-learning, such a duration might be insufficient.

"... I now said that am going to give them four hours of the class to do SL which will be two weeks .. the first two weeks they will use that period so that they will not be telling me they don't have time because the time for my course they should use, that is the solution I have provided as a temporary one to take care of the time. It means that at least they have 4hrs of performing some activities" - Gbada

This study identified the challenges faced by participants of service-learning in Nigeria public universities from the in-depth interviews and interactions with the participants. The results confirmed participants experienced difficulties in the process of service-learning implementation due to the absence of documented guidelines for a reference as observed in other studies, (Broussard, 2011; Gemmel \& Clayton, 2009). The major challenge identified was the lack of in-depth knowledge of the process of service-learning implementation Other challenges include inadequate finances, insufficient time, social barriers such as language or communication, poor reception of students by host communities were also identified in the study. The identified challenges were found to have to some extent impeded the optimum benefits the participants could have derived from the program. Of the 
challenges identified in the study, inadequate time and money were more detrimental to the program as others could be easily managed since they were socially induced. Students were able to manage some of the challenges such as financial difficulties by improving or opting for less expensive projects. It was difficult overcoming inadequate time in service-learning, the students attested to not being detailed in some stages or processes during the implementation. This can affect the learning outcome because service-learning follows the order of the experiential learning theory. For maximal learning, each stage serves as a pre-requisite of the other, and participants are meant to progress successfully through each stage (Akinyode \& Khan, 2016).

Furthermore, there is a need for the proper integration of service-learning into Nigerian public institutions. Due to the benefits mentions or identified by the participants. It can be said that the benefits of service-learning far out way the challenges.

\section{Conclusion}

The discussed are the challenges identified to have been experienced by those who participated in servicelearning in the sampled Nigerian universities. Observation showed most of these challenges were common to all the institutions except for the Northern University where service-learning has been officially adopted as a method for teaching and learning. However, studies found that the major process of implementation of service-learning such as reflection was poorly engaged due to limited knowledge students had and inadequate supervision. Conclusively, although students experienced some challenges during the implementation of service-learning, it can also be said that this aided in the development of some enviable characters such as the ability to improvise yielding an improved creative ability in students, altruism which when sustained can lead to the development of a lifelong sense of philanthropist and an ability to work independently. In summary, based on the research conducted, findings showed service-learning as a novel phenomenon in the Nigerian education system, hence some of the obvious challenges. Having identified the challenges experienced even though some were not envisaged before the commencement of the activities, studies showed, discoveries were also made on how solutions were proffered to the challenges experienced. Although participants could not proffer solutions to some, however, suggestions were made on how to ameliorate such difficulties for reference purposes.

\section{Recommendations}

Based on the data obtained as a result of the study, it is seen that the students have problems in the fieldspecific skills such as understanding, interpretation, thinking and reasoning in the new examination system. On the other hand, the opinion is that the textbooks and the exam are not parallel, so teachers have various difficulties. In this direction, various activities can be organized to increase students' motivation and to gain reading habit. By making use of constructivist teaching methods and techniques, learning environments where students can construct knowledge can be designed and studies can be done accordingly. In addition, it is thought that it would be beneficial to provide teachers with in-service training for the exam.

\section{References}

Abes, E. S., Jackson, G., \& Jones, S. R. (2002). Factors that motivate and deter faculty use of service-learning. Michigan Journal of Community Service Learning, 9(1).

Akinyode, B. F., \& Khan, T. H. (2016). Students' learning style among planning students in Nigeria using Kolb's learning style inventory. Indian Journal of Science and Technology, 9(47).

Al Barwani, T., Al-Mekhlafi, A., \& Nagaratnam, R. P. (2013). Service-learning might be the key: Learning from the challenges and implementation strategies in EFL teacher education in Oman. International Journal of Instruction, 6(2), 109-128.

Bringle, R. C., Clayton, P., \& Price, M. (2012). Partnerships in service learning and civic engagement. Partnerships: A Journal of Service-Learning and Civic Engagement, 1(1).

Brondani, M. A. (2012). Teaching social responsibility through community service-learning in predoctoral dental education. J Dent Educ, 76(5), 609-619. Retrieved from http://www.ncbi.nlm.nih.gov/pubmed/22550107

Broussard, B. B. (2011). The Bucket List: a service-learning approach to community engagement to enhance community health nursing clinical learning. J Nurs Educ, 50(1), 40-43. doi:10.3928/01484834-20100930-07

Brown, R. B. (2006). Doing your dissertation in business and management: the reality of researching and writing: Sage.

Burth, H.-P. (2016). The contribution of service-learning programs to the promotion of civic engagement and political participation: A critical evaluation. Citizenship, Social and Economics Education, 15(1), 58-66.

Cho, J., \& Trent, A. (2006). Validity in qualitative research revisited. Qualitative Research, 6(3), 319-340.

Corporation., R. R. (2009). K-12 Service-Learning Project Planning Toolkit

Scotts Valley,America: National Service-Learning Clearinghouse, Retrieved from www.servicelearning.org/filemanager/download/K-12_Service-Learning_Project_Planning_Toolkit.pdf

Creswell, J. W. (2007). Qualitative Inquiry and Research Design: Choosing Among Fire Traditions (2nd edition ed.). California, U.S.A: SAGE Publications. 
Creswell, J. W. (2012). Qualitative inquiry and research design: Choosing among five approaches: Sage.

Creswell, J. W., \& Clark, V. L. P. (2011). Designing and conducting Mixed Methods Research (2nd Edition ed.). California, USA: SAGE Publication.

Darby, A., \& Newman, G. (2014). Exploring faculty members' motivation and persistence in academic servicelearning pedagogy. Journal of Higher Education Outreach and Engagement, 18(2), 91-119.

Deba, A. A., Jabor, M. K., Buntat, Y., \& Musta'mal, A. H. (2014). Potential of Service-Learning on Students' Interpersonal Skills Development in Technical and Vocational Education. Asian Social Science, 10(21), 1.

Dewey, J. (2004). Democracy and education: Courier Corporation.

Fenton, L., \& Gallant, K. (2016). Integrated Experiential Education: Definitions and a Conceptual Model. The Canadian Journal for the Scholarship of Teaching and Learning, 7(2), 7.

Fiske, E. B. (2002). Learning in Deed: The Power of Service-Learning for American Schools.

Gbadamosi, T. (2018). Where Are We? Lecturers Receptivity Of Service-learning In Nigeria. International journal of Social Science, 4(2), 11.

Gemmel, L. J., \& Clayton, P. H. (2009). A comprehensive framework for community service-learning in Canada: Canadian Alliance for Community Service-Learning.

Kaye, C. B. (2010). The Complete Guide to Service Learning: Proven, Practical Ways to Engage Students in Civic Responsibility, Academic Curriculum, \& Social Action: Free Spirit Publishing.

Kaye, C. B. (2013). The Five Stages of Service Learning. Education Week. http://blogs. edweek. org/edweek/global_learning/2013/06/five_stages_of_service_learning. html.

Knapp, T., Fisher, B., \& Levesque-Bristol, C. (2010). Service-learning's impact on college students' commitment to future civic engagement, self-efficacy, and social empowerment. Journal of Community Practice, 18(2-3), 233-251.

Kolb, A. Y. K. D. A. (2017). Experiential Learning Theory as a Guide for Experiential Educators in Higher Education. Journal for Engaged Educators, Vol. 1, (No. 1 ), 37.

Kolb, D. A. (2014). Experiential learning: Experience as the source of learning and development: FT press.

Maakrun, J. (2016). International service learning: benefits to African teachers. Journal of Service-Learning in Higher Education, 5(1), n1.

Malterud, K. (2001). Qualitative research: standards, challenges, and guidelines. The Lancet, 358(9280), 483488. doi:10.1016/s0140-6736(01)05627-6

Mayer, R. E. (2009). Constructivism as a theory of learning versus constructivism as a prescription for instruction. Constructivist instruction: Success or failure, 184-200.

Miettinen, R. (2000). The Concept Of Experiential Learning And John Deweys's.

Miles, M. B., \& Huberman, A. M. (1994). An Expanded Source Book: Qualitative Data Analysis (2nd edition ed.): Thousand Oaks, CA: Sage.

Mileusnić, M. (2020). Service learning in geoscience education. European Geologist(50), 6-9.

Morton, K. (1995). The irony of service: Charity, project and social change in service-learning. Michigan Journal of Community Service Learning, 2(1), 19-32.

Ojala, M. (2008). Recycling and Ambivalence: Quantitative and Qualitative Analyses of Household Recycling Among Young Adults. Environment and Behavior, 40(6), 777-797. doi:10.1177/0013916507308787

Olagoke-Oladokun, L. I., Mokhtar, M., Gbadamosi, T. V., \& Dugguh, S. I. (2020). IMPACT OF SERVICELEARNING AMONG UNIVERSITY STUDENTS IN NIGERIA. PalArch's Journal of Archaeology of Egypt/Egyptology, 17(7), 4947-4958.

Palmer, C. E., \& Savoie, E. J. (2002). Challenges to connecting sociology and service learning. Sociological Practice, 4(1), 89-97.

Rusu, A. S., Copaci, I. A., \& Soos, A. (2015). The Impact of Service-Learning on Improving Students’ Teacher Training: Testing the Efficiency of a Tutoring Program in Increasing Future Teachers' Civic Attitudes, Skills and Self-Efficacy. Procedia - Social and Behavioral Sciences, 203, 75-83. doi:http://dx.doi.org/10.1016/j.sbspro.2015.08.262

Schelbe, L., Petracchi, H. E., \& Weaver, A. (2014). Benefits and challenges of service-learning in Baccalaureate Social Work Programs. Journal of Teaching in Social Work, 34(5), 480-495.

Schoenherr, T. (2015). Service-Learning in Supply Chain Management: Benefits, Challenges and Best Practices. Decision Sciences Journal of Innovative Education, 13(1), 45-70.

Smith, J. A., \& Osborn, M. (2003). Interpretative Phenomenological Analysis. In J. A. Smith (Ed.), Qualitative psychology: A practical guide to research methods (pp. 51-80). London: Sage.

Spring, K., Grimm Jr, R., \& Dietz, N. (2008). Community Service and Service-Learning in America's Schools. Corporation for National and Community Service.

Stewart, T., \& Wubbena, Z. (2014). An overview of infusing service-learning in medical education. Int J Med Educ, 5, 147-156. doi:10.5116/ijme.53ae.c907

Tryon, E., Stoecker, R., Martin, A., Seblonka, K., Hilgendorf, A., \& Nellis, M. (2008). The Challenge of ShortTerm Service-Learning. Michigan Journal of Community Service Learning, 14(2), 16-26. 
Tyran, K. L. (2017). Transforming students into global citizens: International service learning and PRME. The International Journal of Management Education, 15(2, Part B), 162-171. doi:https://doi.org/10.1016/j.ijme.2017.03.007

Wade, R. C. (1997). Community service-learning: A guide to including service in the public school curriculum: SUNY Press.

Young, B. R., Williamson, H. J., Burton, D. L., Massey, O. T., Levin, B. L., \& Baldwin, J. A. (2015). Challenges and Benefits in Designing and Implementing a Team-Based Research Mentorship Experience in Translational Research. Pedagogy Health Promot, 1(4), 233-246. doi:10.1177/2373379915600174 